Tersedia online di: http://ejournal-balitbang.kkp.go.id/index.php/jkpt

\title{
DISTRIBUSI SPASIAL IKAN FAMILI SCARIDAE DI PERAIRAN TAMAN NASIONAL BUNAKEN, SULAWESI UTARA
}

\section{SPATIAL DISTRIBUTION OF SCARIDAE FAMILY FISHES IN THE BUNAKEN NATIONAL PARK, NORTH SULAWESI}

\author{
Basuki Rachmad\#, Ratna Suharti, Disty Anisaa Irayana, dan Dadan Zulkifli \\ Sekolah Tinggi Perikanan
}

Jl. AUP Pasar Minggu Jakarta Selatan 12520, Telepon (021) 7806874, 78830275 faks (021) 7805030, 78830275

E-mail: basukistp@yahoo.co.id

(Diterima: 22 November 2018; Diterima setelah perbaikan: 9 Januari 2019; Disetujui: 9 Januari 2019)

\begin{abstract}
ABSTRAK
Ikan karang Famili Scaridae adalah salah satu ikan herbivora yang hidup di ekosistem terumbu karang. Namun keberadaan dan kondisi ikan ini belum banyak diketahui di perairan Taman Nasional Bunaken. Penelitian ini bertujuan untuk mengetahui komposisi dan distribusi ikan famili Scaridae yang berhubungan dengan terumbu karang, di Taman Nasional Bunaken yang dilakukan di tiga pulau pada bulan Februari hingga Mei 2017. Pengamatan ini dilakukan dengan metode sensus visual Line Intercept Transect (LIT). Dalam penelitian ini ditemukan keragaman ikan famili Scaridae terdiri dari 9 spesies, dua spesies ikan yaitu Scarus spirus dan S. niger memiliki distribusi spasial di seluruh perairan. Jenis ikan yang memiliki kelimpahan tertinggi adalah $S$. gobbhan (110 ind/ha). Kesamaan spesies dicirikan oleh kecenderungan dari kelompok yang terjadi di perairan Pulau Bunaken yang kerucut. Penilaian ekologi ikan Scaridae menunjukkan bahwa terumbu karang di perairan Taman Nasional Bunaken masih dalam kondisi baik.
\end{abstract}

Kata Kunci: Distribu spasial; Scaridae keanekaragaman; Taman Nasional Bunaken

\begin{abstract}
Coral fishes Scaridae family is one of the herbivorous fishes that live in coral reef ecosystem. But the existence and condition of this fishes has not been widely known in of Bunaken National Park waters. This study aims to determine the composition and distribution of Scaridae family associated with coral reefs, in Bunaken National Park conducted at three islands in February to May 2017. The observation is ware made with the visual census method Line Intercept Transect (LIT) In this study found diversity of Scaridae family consists of 9 species, two species Scarus spirus and S. niger has spatial distribution throughout the waters. S. gobbhan has the highest abundance (110 ind/ha). The similarity of species characterized by the tendency to from groups that occur in the conical Bunaken Island waters. Ecological assessment of the Scaridae fish shows that the coral reefs in the waters of Bunaken National Park are still in good condition.
\end{abstract}

Keywords: Spasial Distributian, Scaridae, diversity, Bunaken National Park

\section{PENDAHULUAN}

Ikan karang merupakan salah satu biota yang berasosiasi pada ekosistem terumbu karang dan hidupnya sangat tergantung pada kondisi terumbu karang tersebut (Laikun, Rondonuwu, Rembet dan Unstain, 2014). Ikan dapat mempengaruhi interaksi komunitas terumbu karang maupun proses ekologi
(Sulisyati, Erny, Lies dan Chafid, 2014). Menurut Hukom (1999), ikan karang mempunyai daerah tertentu yang sesuai dengan kehidupannya. Keberadaaan ikan karang erat kaitannya dengan ketersediaan sumberdaya terumbu karang sebagai habitat (Rondonuwu, Rembet, Unstain, Monigkey, Tombokan, Kambey dan Wantasen, 2013). Umumnya

\# Korespondensi: Sekolah Tinggi Perikanan

E-mail: basukistp@yahoo.co.id 
ikan karang yang memiliki biomassa dan kelimpahan tertinggi dijumpai dalam keadaan berkelompok (schooling) (Setiawan, 2016).

Ikan famili Scaridae (kakatua) ditemukan di terumbu karang dan sangat erat kaitannya dengan terumbu karang. Ikan ini merupakan anggota ikan terumbu karang yang berada di wilayah tropis. Beberapa spesies ikan kakatua memiliki sebaran perpindahan yang luas (Bellwood, 1994). Ikan Scaridae terdiri dari 10 genera dan 90 spesies yang tersebar diwilayah Indo-Pasifik (Allen and Mark, 2012). Menurut FAO (2001), spesies ikan kakatua yang menyebar di Samudera Hindia diduga berasal dari Indonesia bagian barat adalah jenis Hiposcarus harid, H. longiceps; Chlorurus strongylocephalu, C. microrhinos; Scarus russelii, S. schlegeli; S. scaber, S. dimidiatus, S. oviceps; dan S. spinus, $S$. viridifucatus, beberapa spesies ada yang ditemukan di wilayah padang lamun dan algae (Allen \& Mark, 2012).

Ikan kakatua (famili Scaridae) merupakan salah satu ikan herbivora yang hidup di ekosistem terumbu karang dan menjadikan terumbu karang sebagai tempat habitat dan tempat untuk mencari makan. Kegiatan makan ikan ini memiliki peranan penting bagi produksi dan penyebaran terumbu karang, yang dapat mencegah pertumbuhan berlebih dari alga yang ada pada permukaan karang (Lieske and Myers, 1999). Menurut Wibowo, Muhammad dan Rikoh, (2016), ikan herbivora dapat dijadikan sebagai bioindikator kesehatan terumbu karang karena kelompok ikan ini mengontrol pertumbuhan turf algae, makroalgae yang dapat menghambat pertumbuhan karang baru dengan menyediakan substrat terbuka sebagai tempat melekat individu/koloni karang muda.

Taman Nasional Bunaken merupakan kawasan pelestarian alam berbasis kelautan yang dikelola oleh pemerintah dan ditetapkan berdasarkan SK. Menteri Kehutanan No.730/Kpts-II/1991 dengan luas 89.065 Ha. Namun 30-40 tahun yang lalu aktifitas menangkap ikan yang merusak mengakibatkan kerusakan terumbu karang (Bunaken National Park, 2017). Namun kondisi dan keberadaan ikan Kakatua belum banyak diketahui di peraian ini Tujuan penelitian untuk mengetahui komposisi dan sebaran ikan Scaridae yang berasosiasi dengan terumbu karang, di Taman Nasional Bunaken.

\section{BAHAN DAN METODE}

Penelitian ini telah dilaksanakan pada bulan Februari sampai dengan bulan Mei 2017, di perairan Pulau Bunaken (7 stasiun), Pulau Manado Tua (3 stasiun) dan Pulau Siladen (3 stasiun) yang masuk dalam wilayah perairan Taman Nasional Bunaken, Sulawesi Utara (Gambar.1)

Metode penelitian yang digunakan adalah metode survey. Pengambilan data ikan kakatua menggunakan metode Line Intercept Transect (LIT). Identifikasi ikan dilakukan dengan Underwater Visual Census (UVC) dengan bantuan kamera untuk mendokumentasi spesies ikan yang belum teridentifikasi ketika

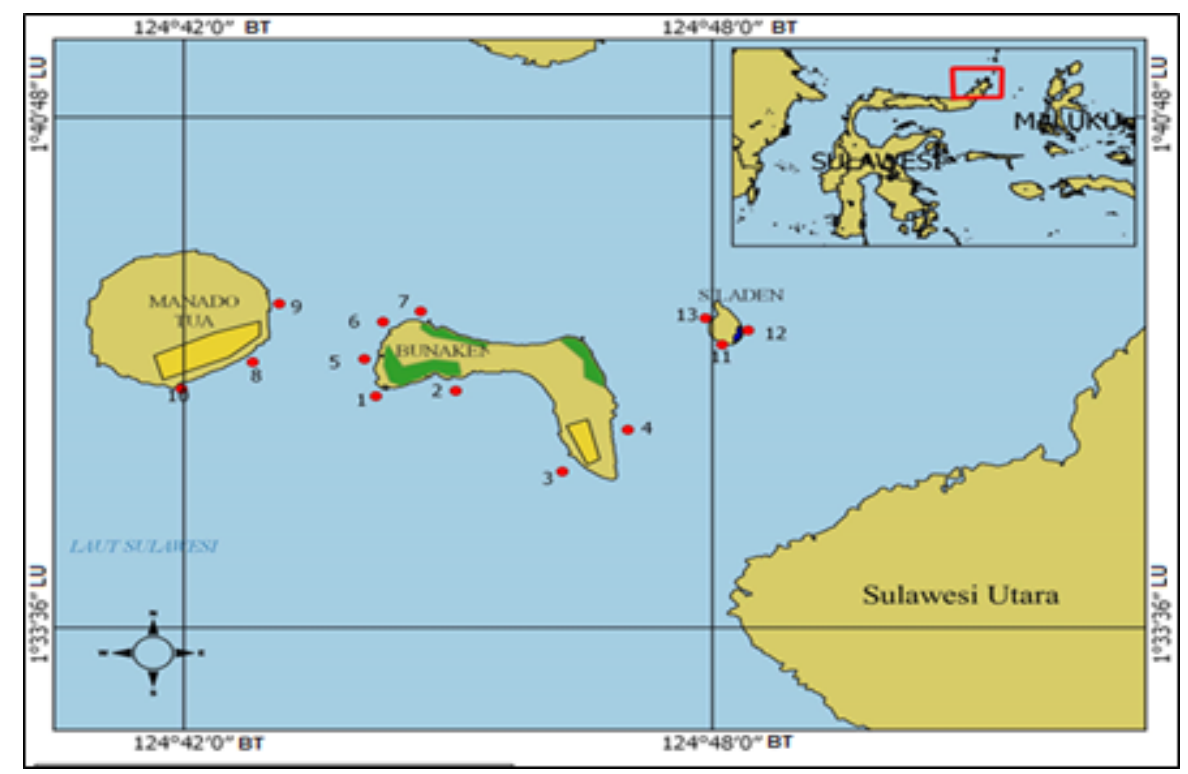

Gambar 1. Stasiun Pengamatan

Figure 1. Observation Stations 
penyelaman (Nurjirana, 2016). Jenis ikan diidentifikasi melalui hasil video yang telah direkam pada saat penyelaman dengan menggunakan buku identifikasi Allen, Steene, Human and Deloach (2003), Allen \& Mark (2012), Kuiter and Tonozuka (2001) dan Setiawan (2010). Kelimpahan jenis ikan dihitung sepanjang garis transek 70 meter 2,5 meter ke kiri dan kanan garis transek, analisis untuk kelimpahan ikan menggunakan persamaan sebagai berikut (English,Wilkinson and Baker, 1997) :

$$
\mathrm{D}=\frac{\mathrm{ni}}{\mathrm{A}}
$$

Keterangan :

D = Kelimpahan Spesies (ind/ha)

$\mathrm{n}_{\mathrm{i}}=$ Jumlah Individu ikan jenis ke-i

$\mathrm{A}=$ Luas area sensus ikan

Indeks keanekaragaman (H') digunakan untuk mendapatkan gambaran populasi secara matematis agar dengan mudah menganalisis informasi jumlah individu masing masing jenis dalam suatu komunitas (Setyawan dan Yusri, 2011). Perhitungan menggunakan rumus berdasarkan (Odum, 1993) :

$$
\mathrm{H}^{\prime}=-\sum_{\mathrm{i}=1}^{\mathrm{S}}(\mathrm{Pi} . \ln \mathrm{Pi})
$$

Keterangan :

$\mathrm{H}^{\prime}$ : Indeks Keanekaragaman

S : Jumlah taksa ikan Karang

$P_{i}$ : Proporsi jumlah individu pada jenis ikan

1. Bila $H^{\prime} d^{\prime \prime} 2,0$, maka Keanekaragaman rendah, tekanan lingkungan kuat.

2. Bila $H^{\prime}$ berkisar antara $1,0-3,0$ maka Keanekaragaman sedang, tekanan lingkungan sedang.

3. Bila $\mathrm{H}^{\prime} \tilde{\mathrm{A}} 3,0$ maka keanekaragaman tinggi

Indeks keseragaman digunakan untuk melihat keseimbangan komunitas ikan karang dengan cara mengukur besarnya keserupaan dari total individu antar jenis dalam komunitas (Setyawan \& Yusri, 2011). Rumus yang digunakan berdasarkan Odum (1993) :

$$
\mathrm{E}=\frac{\mathrm{H}^{\prime}}{\mathrm{H}^{\prime} \text { maks }}
$$

Keterangan :

$$
\begin{aligned}
& E \quad \text { : Indeks Keseragaman } \\
& H \text { Maks : Indeks Keragaman Maksimum }=\text { In } S \\
& \mathrm{~S} \quad \text { : Jumlah Individu }
\end{aligned}
$$

Nilai indeks berkisar antara 0-1 dengan kriteria sebagai berikut :

1. $E \leq 0,5$ : Komunitas tertekan

2. $0,5<E \leq 0,75$ : Komunitas sedang, komunitas labil

\section{3. $E>0,75$ : Komunitas stabil}

Jika $E$ menurun, maka nilai $\mathrm{H}^{\prime}$ juga menurun, menandakan adanya dominansi (C) suatu jenis terhadap jenis-jenis lainnya (Setyawan \& Yusri, 2011). Rumus yang digunakan berdasarkan Odum (1993) adalah :

$$
C=\sum_{i-1}^{s}(p i)^{2}
$$

Keterangan:

$\mathrm{C}=$ Indeks Dominansi

$p i=$ Rasio jumlah individu pada spesies ikan karang Indeks dominasi Simpson memiliki kisaran
1. $0,0<D \leq 0,5$
: Dominansi rendah
2. $0,5<D \leq 0,75$
: Dominansi sedang
3. $0,75<D \leq 1$
: Dominansi Tinggi

Sedangkan untuk menetapkan status ekologi ikan kakatua digunakan nilai indeks ekologi dengan melihat kriteria skoring (McMellor, 2007), tingkat kesamaan keberadaan jenis-jenis ikan menggunakan analisis klaster yaitu suatu metode yang digunakan untuk mengklasifikasikan obyek ke dalam kelompok yang relatif homogen yang dinamakan klaster. Obyek dalam setiap kelompok cenderung mirip satu sama lain dan berbeda jauh dengan obyek dari klaster lainnya, dengan menggunakan clustering ini, kita dapat mengklasifikasikan objek, menemukan pola-pola distribusi secara keseluruhan, dan menemukan keterkaitan antara atribut data (Metisen dan Herlina, 2015) Pengolahan data analisa pengelompokan hierarki dilakukan dengan bantuan program Statistica.

\section{HASIL DAN PEMBAHASAN}

Keanekaragaman ikan kakaktua di perairan Taman Nasional Bunaken sejumlah 2 genera dan 9 spesies (Tabel 1).

Jumlah spesies ikan Scaridae yang ditemukan di Pulau Bunaken adalah sebanyak 7 spesies yang mendominasi oleh Scarus gobbhan (110 ind/ha). Sedangkan yang paling sedikit adalah jenis Scarus chameleon dan Chlorurus bleekeri dengan nilai kelimpahan masing-masing 4 ind/ha.

Jumlah ikan Scaridae yang ditemukan di Pulau Manado Tua adalah 6 spesies. Jenis ikan Scarus gobbhan, Scarus chameleon, dan Scarus niger memiliki 
Tabel 1. Kehadiran dan Kelimpahan Spesies Ikan Famili Scaridae yang ditemukan di Perairan Taman Nasional Bunaken

Table 1. Presence and Abundance of Scaridae Family Found in Bunaken National Park Waters

\begin{tabular}{llccc}
\hline \multirow{2}{*}{ No. } & \multicolumn{3}{c}{ Spesies } & \multicolumn{3}{c}{ Kelimpahan ikan (ind/ha) } \\
\cline { 3 - 5 } & & P. Bunaken & P. Manado Tua & P. Siladen \\
\hline 1. & Scarus gobbhan & 110 & 48 & 0 \\
2. & S. quoyi & 61 & 0 & 0 \\
3. & S. chameleon & 4 & 48 & 0 \\
4. & S. prasiognathus & 0 & 10 & 0 \\
5. & S. spinus & 33 & 10 & 48 \\
6. & S. niger & 16 & 48 & 38 \\
7. & S. pyrrhurus & 0 & 0 & 29 \\
8. & Chlorurus micrirhins & 8 & 10 & 0 \\
9. & C. bleekeri & 4 & 0 & 0 \\
\hline \multicolumn{2}{c}{ Jumlah } & 237 & 171 & 114 \\
\hline
\end{tabular}

nilai kelimpahan masing-masing adalah 48 ind/ha, sementara di Pulau Siladen hanya ditemukan 3 spesies yang tertinggi yaitu Scarus spirus (48 ind/ha). Dua spesies ikan yaitu Scarus spirus dan S. Niger ditemukan di semua perairan Taman Nasional Bunaken. Kelimpahan ikan Scaridae yang ditemukan tertinggi di Pulau Bunaken dan yang terendah di Pulau Siladen (Scarus gobbhan sebesar 110 ind/ha). Ikan family Scaridae di Pulau Bunaken memiliki jumlah individu paling banyak dan keanekaragaman yang tinggi dibanding Pulau Manado Tua dan Siladen, hal ini terjadi karena Pulau Bunaken terdapat zona inti yang di daerah tersebut tidak boleh dilakukan aktivitas apapun sehingga keadaan ekosistem terumbu karang yang merupakan habitatnya masih bagus kondisinya.

Hasil analisis indeks biologi ikan famili Scaridae (Gambar 2), indeks keanekaragaman di Pulau Bunaken dan Pulau Manado Tua dengan nilai berturut-turut 1,42 dan 1,549 yang termasuk termasuk kategori keanekaragaman sedang, ini menunjukan bahwa penyebaran jumlah individu tiap jenis stabil, dan tekanan ekologi sedang. Sementara nilai keanekaragaman di Pulau Siladen yaitu sebesar 0,71 yang termasuk kategori rendah.

Nilai indeks keseragaman ikan Scaridae pada Pulau Bunaken, Manado Tua dan Siladen berkisar antara 0,65 $-0,86$ yang berarti keseragaman ikan Scaridae masuk kategori sedang pada hampir tiap stasiunnya yang menyebabkan keseimbangan komunitas jenis ikan Scaridae pada ketiga pulau ini. Sedangkan indeks dominansi ikan Scaridae pada tiga pulau berkisar antara $0,24-0,35$, nilai tersebut dalam kategori rendah, nilai rendah tersebut mengindikasikan bahwa tidak ada spesies ikan Scaridae yang mendominasi pada seluruh

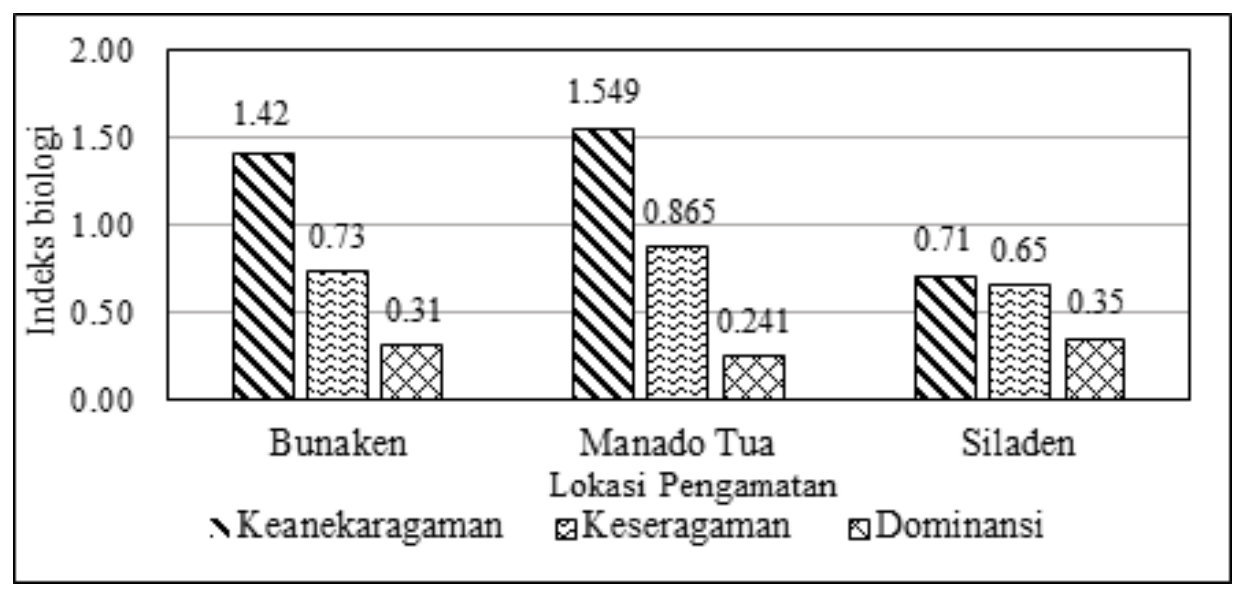

Gambar 2. Nilai Indeks Biologi Ikan Famili Scaridae di Perairan Taman Nasional Bunaken.

Figure 2. Biological Index of Scaridae Family Fish in Bunaken National Park Waters. 
lokasi pengamatan. Nilai indeks keseragaman berhubungan dengan jumlah kehadiran jenis dan pola distribusi jumlah masing-masing populasi dalam komunitas, kemerataan populasi menunjukan bahwa lingkungan memberikan kesempatan yang sama untuk semua populasi berkembang, sebaliknya ketika lingkungan hidup memburuk hanya populasi tertentu yang bertahan dan berkembang, dan kemudian populasi ini akan mendominasi dalam komunitas (Edrus, Wijaya, dan Setyawan, 2013)

Dari hasil penilaian ekologi ikan Scaridae (Tabel 2) bahwa di perairan Pulau Bunaken, Pulau Manado Tua dan Pulau Siladen menunjukkan nilai kelimpahan ikan lebih dari 6 individu yang termasuk kategori sangat baik.

Seluruh lokasi pengamatan memiliki kondisi ekologi yang masih dalam kondisi baik artinya kondisi ekosistem terumbu karang sebagai habitat dari ikan karang dan biota lainnya masih dalam kategori baik, diduga ikan Scaridae pada tiap lokasi pengamatan memangsa alga dan mikroorganisme yang tumbuh berlebih pada terumbu karang sehingga terjadi keseimbangan ekosistem.

Hasil analisis kesamaan untuk melihat distribusi antar lokasi penelitian dengan menggunakan tingkat kesamaan kehadiran ikan terbagi dalam 2 kelompok yang memiliki kehadiran spesies yang sama yaitu kelompok pertama terdiri dari Pulau Manado Tua dan pulau Siladen sebesar 23,7\%, kelompok kedua adalah Pulau Bunaken (Gambar 3).

Dari kedua kelompok tersebut, kelompok 2 dimana individu ikan Scaridae yang ditemukan di Pulau Mando

Tabel 2. Kondisi Ikan Famili Scaridae berdasarkan Kriteria Penilaian Ekologi Ikan Karang di Perairan Taman Nasional Bunaken (Mc.Mellor, 2007)

Table 2. Scaridae Family Conditions Based on the Coral Fish Ecological Assessment Criteria at Bunaken National Park Waters (Mc. Mellor, 2007)

\begin{tabular}{llcccc}
\hline No & Lokasi Pengamatan & $\begin{array}{c}\text { Individu yang } \\
\text { ditemukan } \\
\text { (ind/1.250 } \mathbf{~ m}^{\mathbf{3}} \text { ) }\end{array}$ & Jumlah & Skor & Kriteria \\
\hline 1. & Pulau Bunaken & 15 & $>6$ & 5 & Sangat baik \\
2. & Pulau Manado Tua & 11 & $>6$ & 5 & Sangat baik \\
3. & Pulau Siladen & 7 & $>6$ & 5 & Sangat baik \\
\hline
\end{tabular}

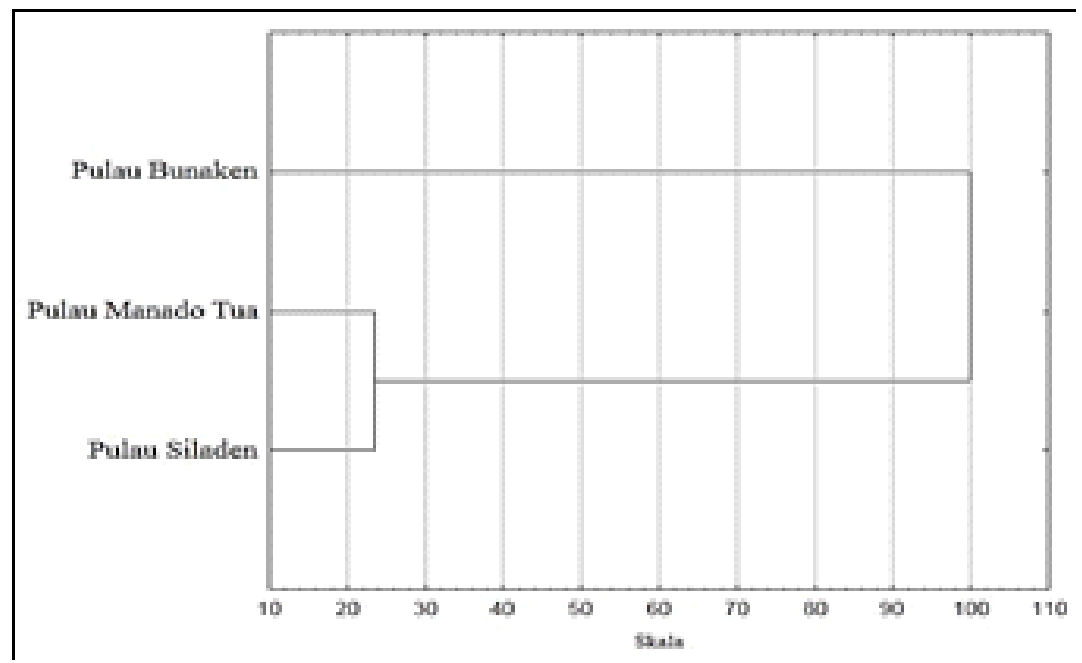

Gambar 3. Tingkat Kesamaan Lokasi Pengamatan Berdasarkan Kehadiran Spesies Ikan Famili Scaridae yang Ditemukan di Perairan Taman Nasional Bunaken.

Figure 3. Level of Similarity of Location of Observation Based on Presence of Fish Species Scaridae Family Found in Bunaken National Park Waters. 
Tua dan Siladen yang diduga memiliki tingkatan kemiripan paling besar dengan nilai 23,7\%. Pulau Manado Tua dan Siladen diduga memiliki kemiripan karakterisitik ekosistem terumbu karang yang merupakan habitat ikan Scaridae dan kondisi lingkungan yang mendukung untuk kehidupan ikan tersebut, sehingga jumlah ikan yang ditemukan pada kedua pulau memiliki tingkat kemiripan yang besar.

Pada tingkat kesamaan jenis dan kelimpahan ikan Scaridae antar lokasi penelitian terbagi menjadi 2 kelompok, kelompok pertama Scarus prasiognathus, Chlorurus bleekeri, dan Chlorurus micrirhins, Scarus pyrrhurus, Scarus chameleon, Scarus niger dan Scarus quoyi dengan nilai 68,92\%. Kelompok kedua adalah ikan Scarus gobbhan. Kelompok yang memiliki tingkat kemiripan jumlah individu paling besar adalah spesies Scarus prasiognathus, Chlorurus bleekeri, dan Chlorurus micrirhins dengan nilai 10,31\% (Gambar 4).

Tingkat kesamaan jumlah individu ikan Scaridae antara tiap lokasi pengamatan yang terdiri dari 2 kelompok besar. Kelompok 1 yaitu antara ikan Scarus gobbhan dengan seluruh spesies ikan Scaridae yang ditemukan di tiap lokasi pengamatan dengan nilai 100\%. Kelompok 2 antara Scarus quoyi dengan Scarus chameleon, Scarus prasiognathus, Scarus pyrrhurus, Scarus niger, Scarus spirus, Chlorurus micrirhins, Chlorurus bleekeri dengan nilai 68,92\%. Kelompok yang memiliki tingkat kemiripan jumlah individu paling besar adalah spesies Scarus prasiognathus, Chlorurus bleekeri, dan Chlorurus micrirhins dengan nilai 10,31\%, menurut Mujiyanto dan Hartati (2011) semakin kecil skala cluster, maka semakin besar tingkat kesamaannya.

Kondisi perairan ketiga pulau menunjukkan bahwa kondisi perairan tidak jauh berbeda pada setiap stasiun dan masih pada batas yang dapat ditoleransi oleh hewan karang dan biota-biota laut, kondisi parameter perairan di lokasi penelitian dapat dilihat pada Tabel 3.

Suhu pada perairan ketiga pulau berkisar antara 27-30 ${ }^{\circ} \mathrm{C}$, nilai tersebut masih berada dalam batas toleransi dimana biota karang masih dapat tumbuh dengan baik. Yuspriadipura, Suprapto dan Suryanti, (2014) mengatakan bahwa ikan karang masih dapat

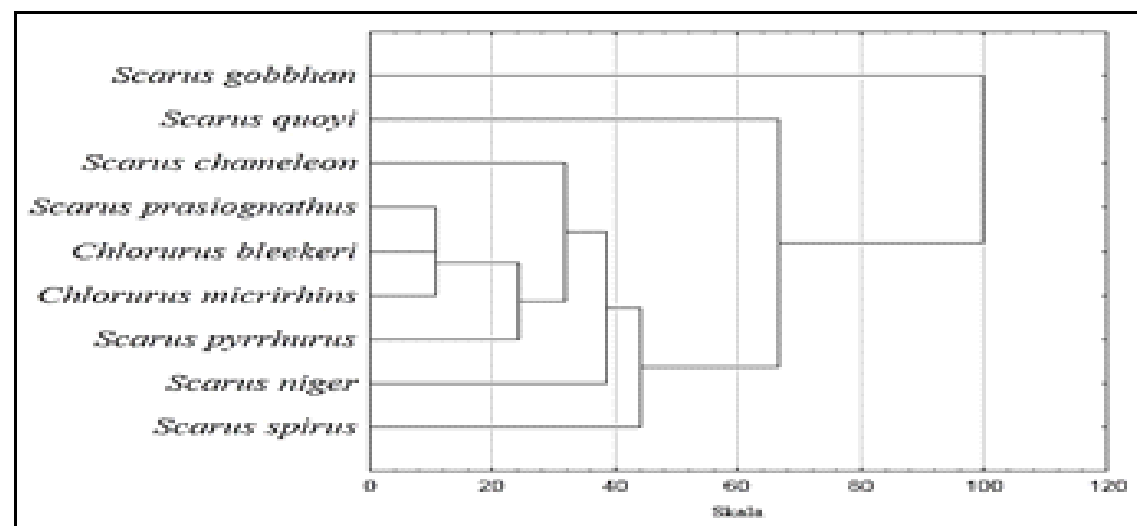

Gambar 4. Tingkat Kesamaan Jenis Ikan Famili Scaridae antar Lokasi Pengamatan di Perairan Taman Nasional Bunaken.

Figure 4. Level of Similarity between Scaridae Family Types between Observation Locations at Waters of Bunaken National Park Waters.

Tabel 3. Parameter Pembatas Perairan Pulau Bunaken, Manado Tua dan Siladen

Table 3. Measurement results of water quality parameters on Bunaken Island, Manado Tua and Siladen

\begin{tabular}{lcccc}
\hline \multirow{2}{*}{ Parameter } & \multicolumn{4}{c}{ Lokasi dan Baku Mutu } \\
\cline { 2 - 5 } & Bunaken & Manado Tua & Siladen & Baku Mutu \\
\hline Suhu $\left({ }^{\circ} \mathbf{C}\right)$ & $28-30$ & $27-30$ & $28-30$ & $28-30$ \\
Salinitas (\%o) & $29-32$ & $29-32$ & 31 & $33-34$ \\
Kecerahan (m) & 7 & 7 & 7 & $>5 \mathrm{~m}$ \\
Arus (m/s) & $0,04-0,09$ & $0,07-0,15$ & $0,04-0,13$ & - \\
\hline
\end{tabular}


mentoleransi suhu sampai antara $>25^{\circ} \mathrm{C}$. Salinitas perairan berkisar 29-32\% Menurut Nybakken (1992) Terumbu Karang dapat bertahan hidup pada salinitas laut normal yaitu 32-35\% Nilai salinitas di perairan pada tiap stasiun masih dapat ditoleransi oleh ikan karang. Wibisono (2005) menyatakan salinitas yang ideal untuk pertumbuhan karang adalah 30-32 \%. Pengaruh salinitas terhadap kehidupan binatang karang sangat bervariasi tergantung pada kondisi periaran laut setempat (Supriharyono, 2007). Kecerahan perairan adalah $100 \%$ pada kedalaman 7 meter, perairan tersebut tergolong perairan yang masih bersih, dimana cahaya yang masuk ke perairan dapat menembus dengan sempurna hingga kedalaman $7 \mathrm{~m}$. Kecepatan arus di 13 lokasi stasiun pengamatan berkisar antara 0,04-0,15 m/s. Besarnya kecepatan arus mempengaruhi pertumbuhan terumbu karang sebagai habitat ikan karang. Pergerakan arus berperan dalam proses aliran makanan dan oksigen serta membantu membersihkan timbunan kotoran dan endapan yang menempel pada polip karang. Arus juga berperan dalam proses fertilisasi dan distribusi ikan karang terutama dalam masa spawning dan larva (Nybakken, 1992; Nontji, 2007; Maharbahakti, 2009).

\section{KESIMPULAN}

Keanekaragaman ikan family Scaridae di Taman Nasional Bunaken terdiri dari 9 spesies, Pulau Bunaken memiliki kelimpahan ikan Scaridae tertinggi ( 237 ind/ ha) dan terendah di Pulau Siladen (114 ind/ha). Nilai indeks keanekaragaman dan keseragaman ikan Scaridae pada ketiga pulau termasuk kategori sedang, nilai indeks dominansi rendah menunjukkan tidak ada jenis yang mendominasi pada tiap lokasi pengamatan. Dua spesies ikan yaitu Scarus spinus dan S. Niger memiliki distribusi spasial di seluruh perairan. Jenis ikan yang memiliki kelimpahan tertinggi adalah $S$. gobbhan sebesar 110 ind/ha. Pengelompokan kesamaan spesies membentuk kelompok yang mengerucut ke perairan Pulau Bunaken, menunjukkan bahwa hampir seluruh spesies yang ditemukan terdapat di Pulau Bunaken. Penilaian ekologi terhadap ikan Scaridae menunjukan bahwa keadaan terumbu karang di perairan Taman Nasional Bunaken masih dalam keadaan baik. Kondisi perairan ketiga pulau yaitu, suhu, salinitas kecepatan arus pada termasuk kategori yang masih baik untuk kehidupan terumbu karang dan biota yang hidup disekitarnya.

\section{UCAPAN TERIMA KASIH}

Penulis mengucapkan terima kasih kepada Ketua Sekolah Tinggi Perikanan dan Taman Nasional Bunaken, Sulawesi Utara.

\section{DAFTAR PUSTAKA}

Allen, G., Steene R., Humann P. \& Deloach N., (2003). Reef Fish Indentification Tropical Pasific. New World Publications, Jacksonville, 480 pp

Allen, G. R. \& Mark V. E. (2012). Reef Fishes of The East Indies. Volume II. Tropical Reef Research, Perth, Australia

Bellwood, D., R. (1994). A Phylogenetic Study of the Parrotfishes Family Scaridae (Pisces: Labroidei), with a Revision of Genera. Records of The Australian Museum, Supplement 20. Departement of Marine Biology, James Cook University of North Queensland, Australia.

Bunaken National Park. (2017). Buku Informasi Taman Nasional Bunaken. Manado.

Edrus, I. N., Wijaya, S. W. dan Setyawan, I. E. (2013). Struktur Komunitas Ikan Karang di Perairan Pulau Raya, Pulau Rusa, Pulau Rinoi dan Rubiah, Nanggroe Aceh Darussalam. Jurnal Lit. Perikanan Indonesia, Vol. 19 No. 4 : 175-186. Balai Penelitian Perikanan Laut. Jakarta.

English S., C.Wilkinson, \& V. Baker, (1997). Survey Manual For Tropical Marine Resource ( $2^{\text {nd }}$ Edition). Australian Institute of Marine Science. Australia. $X ; 330 p$.

[FAO] Food and Agriculture Organization of The United Nations. (2001). The Living Marine Resources of The Western Central Pacific. Carpenter, K.E.; Niem, V.H. (eds). Vol. 6, Bony Fishes Part 4 (Labridae to Latimeriidae), estuarine crocodiles, sea turtles, sea snakes and marine mammals. Roma.

Hukom, F. D., (1999). Ekostruktur dan Distribusi Spasial Ikan Karang (Famili Labridae) di Perairan Teluk Ambon. Pros. Lok. Pengelolaan \& Iptek Terumbu Karang Indonesia. Jakarta, 22-23 November 1999 : 134-145.

Kuiter, R. H. \& Tonozuka T., (2001). Pictorial Guide to Indonesian Reef Fishes Zoonetics

Laikun, J., Rondonuwu, A. B., Rembet, Unstain. N.W.J. (2014). Kondisi Ikan karang Famili Chaetodontidae di Daerah Perlindungan laut Desa Bahoi kecamatan Likupang Barat kabupaten Minahasa Utara. Jurnal Ilmiah Platax Vol. 2:(3).

Lieske, E., and Myers, R. (1999). Coral Reef Fishes on Wikipedia. 2nd edition. Princeton University Press. ISBN 0-691-00481-1.

Maharbahakti, H. R. (2009). Hubungan Kondisi terumbu Karang dengan Keberadaan Ikan Chaetodontidae di Perairan Pulau Abang, Batam. Pascasarjana Institut Pertanian Bogor. Bogor.

McMellor, S. (2007). A Conservation Value Index to facilitate coral reef evaluation and assessment. A 
thesis submitted for the degree of Doctor of Philosophy, Department of Biological Sciences, University of Essex,

Metisen, B.M.\& Herlina L.S., (2015). Analisis Clustering Menggunakan Metode K-Means dalam Pengelompokkan Penjualan Produk pada Swalayan Fadhila. Jurnal Media Infotama. Vol 11 (2) : hal 110118

Mujiyanto dan Hartati S.T., (2011). Komposisi dan Kelimpahan Stok Ikan Karang serta Pertumbuhan Biota Penempel pada Terumbu Karang Buatan di Teluk Saleh, Nusa Tenggara Barat. Jurnal Penelitian Perikanan Indonesia. Vol. 17 No. 1. Hal 51-59.

Nontji, A. (2007). Laut Nusantara. Edsi Revisi, Cetakan ke-5. Djambatan. Jakarta.

Nurjirana, (2016). Kelimpahan dan Keanekaragaman Jenis Ikan Famili Chaetodontidae Berdasarkan Kondisi Tutupan Karang Hidup di Kepulauan Spermonde, Sulawesi Selatan. Skripsi Universitas Hasanuddin, Makssar.

Nybakken, J. W. (1992). Biologi Laut : Studi Pendekatan Ekologis. Cetakan ke 6. Gramedia. Jakarta.

Odum, E. P. (1993). Dasar-dasar Ekologi (Edisi Indonesia). Gadjah Mada University Press. Edisi ketiga.

Rondonuwu, A. B., Rembet, Unstain, N.W.J., Monigkey R. Dj. Tombokan, J. L., Kambey, A. D. \& Wantasen, A. S. (2013). Ikan Karang Famili Chaetodontidae Di Terumbu Karang Pulau Para Kecamatan Tatoareng Kabupaten Kepulauan Sangihe. Jurnal Ilmiah Platax, Vol. 1:(4).
Setiawan, F., (2010). Identifikasi Ikan Karang dan Invertebrata Laut. Manado, Indonesia.

Setiawan, F., (2016). Komunitas Ikan Karang Di Perairan Taman Wisata Alam (Twa) Batuangus, Kotamadya Bitung, Provinsi Sulawesi Utara. Jurnal Kelautan. Vol 9 (1) : hal 50-61.

Setyawan, E., \& Yusri, S. (2011). Terumbu Karang Jakarta: Pengamatan Jangka Panjang Terumbu Karang Kepulauan Seribu (2003-2007). Yayasan Terumbu Karang Indonesia.

Sulisyati, R., Erny P., Lies R. W. F \& Chafid F., (2014). Karakteristik Terumbu Karang di Zona Pemanfaatan Wisata Taman Nasional Karimunjawa. Jurnal Kelautan. Vol 19 (3) : hal 139-148.

Supriharyono. (2007). Konservasi Ekosistem Sumberdaya Hayati di Wilayah Pesisir dan Laut Tropis. Pustaka Pelajar. Yogyakarta.

Wibisono, M. S. (2005). Pengantar Ilmu Kelautan. Grasindo. Jakarta.

Wibowo, K., Muhammad A. \& Rikoh M. S., (2016). Status Trofik Ikan Karang dan Hubungan Ikan Herbivora dengan Rekrutmen Karang di Perairan Pulau Pari, Teluk Jakarta. Jurnal Oseanologi dan Limnologi di Indonesia. Vol 1 (2) : hal 73-89.

Yuspriadipura, A., Suprapto, D. \& Suryanti. (2014). Jenis Dan Kelimpahan Ikan Pada Karang Branching Di Perairan Pulau Lengkuas Kabupaten Belitung. Diponegoro Journal of Maquares, Vol. 3, No. 3. Hal. 52-57. 